\title{
DISCURSO PRONUNCIADO POR OCASIÃO DA ENTREGA DO TITULO DE PROFESSOR EMÉRITO À PROF. ' DRA. WANDA DE AGUIAR HORTA
}

Leda Ulson Mattos*

É para mim uma honra ter sido escolhida para prestar uma homenagem à Prof. ${ }^{a}$ Wanda de Aguiar Horta, que tanto trabalhou para esta Escola e pela Enfermagem no Brasil, outorgando-lhe o título de Professor Emérito da Escola de Enfermagem da Universidade de São Paulo.

Não é possível deixar de refletir sobre as dificuldades que sentimos ao tentar homenagear uma pessoa de qualidades tão excepcionais como as da Prof. ${ }^{a}$ Wanda Horta. Criamos o perfil de uma pessoa a partir de nossos próprios sentimentos em relação a ela e esta saudação não pode a isso escapar.

Inteligência penetrante, memória privilegiada, leitora infatigável, sempre dominou a literatura de enfermagem. A sua carreira científica foi rápida e produtiva, tendo introduzido no Brasil o Processo de Enfermagem, hoje uma realidade, aplicado em muitos hospitais e ensinado em quase todas as escolas de enfermagem. Dela se emanava extraordinária força intelectual que nos envolvia e um carisma sem igual.

Educada, gentil sem desmesuras, discreta na sua maneira de ser, modesta na sua posição, estava sempre alerta para os problemas dos que a cercavam. Wanda Horta amava o próximo; e como ela mesma dizia, em um de seus poemas,
"Amar
é conhecer
e respeitar;
é responder,
aceitar
e se desvelar
pelo ser amado".

Sua personalidade marcou uma geração de estudantes. Apesar de exigir de seus alunos uma soma considerável de trabalho nunca pudemos deixar de sentir seu respeito a cada um deles e a confiança em sua capacidade de desenvolvimento.

\footnotetext{
* Professor Titular do Departamento de Enfermagem Médico.Cirúrgica da EEUSP, disciplina Nutriçāo aplicada à Enfermagem.

Vice-Diretora da Escola de Enfermagem da USP.
} 
O que mais marcou nos estudantes não foram as técnicas de ensino elaboradas ou requintadas, mas o valor do agente humano que as utilizava.

Entre estudantes, docentes e pesquisadores a Prof. ${ }^{a}$ Wanda de Aguiar Horta foi uma semeadora, e citando o apóstolo São Paulo, "porque semeou com generosidade, os frutos de sua ação acham-se abundantemente em nossos pensamentos e nossas atividades". A dor e a saudade, que dela sentimos, confundem-se com a estimulante e gratificante memória do que usufruímos com a sua amizade, confiança e personalidade.

No momento em que a Congregação da Escola de Enfermagem outorga à Professora Wanda de Aguiar Horta o título de Professor Emérito nós, docentes, estudantes e funcionários, em nossos pensamentos, agradecemos pelo que fez pela Enfermagem no Brasil, por esta Escola e por todos nós; e, acima de tudo, agradecemos a Deus por nos ter dado a graça de conhecê-la. Entregamos ao Dr. Luiz Emílio Horta o Diploma de Professor Emérito a ela concedido. 